\title{
Investigation into obedience in the face of unethical behavior
}

\author{
Nadiatus Salama, ${ }^{1 *}$ Medina Janneta El-Rahman, ${ }^{2}$ Mahfud Sholihin ${ }^{3}$ \\ ${ }^{1}$ Faculty of Da'wah and Communication, Universitas Islam Negeri Walisongo, Semarang - Indonesia, \\ ${ }^{2}$ Department of Psychology Temple University, Tokyo - Japan, ${ }^{3}$ Faculty of Economics and Business, \\ Universitas Gadjah Mada, Yogyakarta - Indonesia
}

\begin{abstract}
Significant concern about obedience in the face of unethical behavior in many corporate scandals is growing worldwide. However, the issue is underexplored because this type of research is faced by the challenge that the perpetrators are reluctant to harm their image by admitting their wrongdoings. The purpose of this study is to obtain a deeper understanding of the human aspects of obedience in the face of unethical behavior among employees in organizations. Using a qualitative cross-case approach, ten employees were interviewed, representing top, middle, and low-level employees in a broad range of private medium-to-large-sized enterprises. The analysis process involved reducing the raw data into meaningful themes, particularly why employees perform unethical behavior. The study's findings provide complex reasons for obedience in the face of unethical behavior, and it is shown to be the rule and habit of organizations. The respondents also explained why they justified their misbehavior. The employees' viewpoints on obedience in the face of unethical behavior will be useful for organizations to curb unlawful practices in the workplace, as these have detrimental effects on them.
\end{abstract}

Keywords: leadership; obedience; organization; unethical behavior

\begin{abstract}
Abstrak: Kepatuhan terhadap perilaku tidak etis dalam perusahaan telah mengalami peningkatan perhatian di seluruh dunia. Namun, isu tersebut masih kurang diteliti karena susahnya menggali data dari pelaku untuk mau menceritakan perbuatan tidak etis yang telah dilakukan. Tujuan penelitian ini adalah untuk mendapatkan pemahaman yang lebih mendalam tentang aspek kepatuhan di kalangan karyawan terhadap perilaku tidak etis yang terjadi dalam sebuah organisasi. Melalui penggalian data secara kualitatif dari berbagai kasus, peneliti mewawancarai sepuluh responden, yaitu eksekutif puncak perusahaan, manajer, dan karyawan tingkat bawah di berbagai perusahaan swasta golongan menengah hingga besar. Proses analisis yang dilakukan termasuk di dalamnya melakukan reduksi data hingga menjadi tema yang bermakna, khususnya tentang mengapa karyawan melakukan perilaku yang tidak etis. Hasil penelitian ini menunjukkan adanya penjelasan yang kompleks tentang mengapa kepatuhan terhadap perilaku yang tidak etis dianggap sebagai aturan dan kebiasaan dalam organisasi. Responden juga menjelaskan mengapa mereka melakukan pembenaran terhadap perilaku buruktersebut. Kajian tentang pandangan karyawan mengenai kepatuhan terhadap perilaku tidak etis ini bermanfaat bagi organisasi untuk membatasi tindakan yang melanggar hukum karena bisa memberikan dampak yang merugikan bagi organisasi.
\end{abstract}

Kata Kunci: kepemimpinan; kepatuhan; organisasi; perilaku tidak etis *Corresponding Author: Nadiatus Salama (e-mail: nadia@walisongo.ac.id), Faculty of Da'wah and Communication, Universitas
Islam Negeri Walisongo, Jl. Prof. HAMKA, Kampus 3, Semarang 50185-Indonesia. 


\section{Introduction}

Unethical behavior takes place in organizations of all types and across industries worldwide, including Indonesia, where such behavior is widespread and restricts the efficiency of business operations. Previous research has identified various forms of unethical behavior in organizations, especially in corporation, such as corrupt practices, non-office related work, unpaid overtime, embezzlement, carelessness in handling confidential information, activities which pose conflicts of interest (Kaptein \& Avelino, 2005), illegal human resource activities, and smaller-scale dishonesty (Giacalone, Knouse, \& Pollard, 1999).

The media in Indonesia often exposes unethical behavior in organizations. For example, corruption involving PT Jiwasraya, the biggest scandal in Indonesia's history, with a loss of Rp 16.8 trillion (US\$ 1.15 billion) after the embezzlement of insurance premium revenue (Martiar \& Purnamasari, 2020). Another case was the sacking of Ari Askhara, CEO of PT Garuda Indonesia, after his involvement in the smuggling of luxury goods (18 boxes containing a HarleyDavidson Electra Glide Shovelhead motorcycle and two Brompton folding bikes) on a new Airbus A330-900 flown in from Toulouse to Jakarta (MS, 2019). Besides, a study by Ivcevic, Menges and Miller (2020) about employees' experience of pressure to act unethically in the workplace demonstrated that most of the participants had never or rarely experienced such pressures, while $11 \%$ had sometimes done so, $12 \%$ had felt pressure 'often' to "almost always", and $23 \%$, or nearly one in four people, had felt under pressure to do things they knew were unethical. Organizational members generally have experiences that could be described as rule violations (29\%), unhealthy work environments (27\%), lying (27\%), sacrificing safety (9\%), discrimination (3\%), stealing (3\%), and bullying (2\%) (Ivcevic et al., 2020). Meanwhile, $40 \%$ of employees stated that they were often or almost always afraid to criticize their employers and coworkers, 10\% said that nobody would be willing to report wrongdoings, and $10 \%$ declared that those who complained of wrong would be silenced (Ivcevic et al., 2020).

In the work environment, if superior orders a subordinate to perform unethical practices, the compelling desire to obey authority acts as a powerful external stimulus, meaning that the individual is likely obey the order without focusing on how the act will conflict with his or her ethical position (Hoyk \& Hersey, 2009). There are other instances when employees might be aware that an order is unethical. However, the pressure to follow it overrides their superiors' judgment, such as in cases of financial irregularity, misconduct, embezzlement, theft, misuse of company assets or funds, or unrealistic expectation.

This study investigates the blind spots that might prevent employees from evaluating their experiences from an ethical perspective and based on the values that they consciously hold dear. In terms of social learning theories, employees will strive to do what is rewarded by their organization and avoid doing what is punished (Trevino, 1992). By observing what happens to others, they learn vicariously. Employees tend to learn from their leaders and coworkers about what they are supposed to do or not do. On the other hand, leaders are likely to 
be models in relation to their assigned role, status, and success in the organization, together with their power to influence the followers' behavior and outcomes (Treviño \& Brown, 2005). Modeling by leaders can influence whether followers are ethical or unethical. Leaders who engage in unethical behavior create a context that promotes "parallel deviance" (Kemper, 1966), where employees observe and are likely to engage in unethical behavior.

In fact, some organizational members often openly obey unethical or illegal instructions. Theory and research also indicate that employees should obey organizational ethics. There is widespread research on desired behavior by and within organizations from multidisciplinary backgrounds, such as public administration (Caiden, 2007; de Graaf et al., 2010; Doig, 2005), psychology (Zimbardo, 2007), criminology (Harrendorf, 2014; Heath, 2008), sociology (Hamilton \& Biggart, 1985), economics (Cadsby et al., 2006), management (Javaid et al., 2020), and politics (Skitka et al., 2009).

A broad review of the literature illustrates that there are conflicting interests in the workplace. Furthermore, researchers from various backgrounds have attempted to comprehend unethical practices in organizations, and studies have been conducted to understand how such unethical behavior takes place. However, this fundamental insight into human behavior indicates a significant gap between what ethical rules dictate and how organizational members usually behave. The specific unethical behavior of employees in the workplace remains unclear and still requires further exploration. Accordingly, no single descriptive analysis of complying with such behavior is possible; only greatly varied but overlapping identical scenarios exist. Therefore, this study seeks to explore how people can be led into doing things that they know they should not do, and how dangerous the commands of authority figures can be. It also attempts to understand how and why employees accept unethical behavior in the workplace by using an organizational psychology lens. Several psychological mechanisms have been proposed to explain the acceptance of unethical behavior which leads to pathological obedience. Such obedience seems to be based on a mentality that reflects long-term membership patterns (Brannigan, 2012). It may be manifested through unethical leadership that strongly impacts employees' propensity to be unethically obedient (Javaid et al., 2020). Likewise, leaders influence their followers and thus, their ethics "trickledown" to followers at lower levels (Mayer et al., 2009; Schaubroeck et al., 2012).

The study reconsiders what employees understand by obedience and expands on how psychologists have understood the rhetoric itself. Therefore, this research aims to gather appropriate information on the obedience related to unethical behavior among employees in organizations. The study also explores how employees will eventually decide what is right or wrong. It may hopefully be useful for organizations in devising methods of curbing the acceptance of unethical behavior in the workplace.

\section{Method}

This study methodologically investigates the human aspects of obedience in the face of unethical behavior in organizations. The qualitative approach is used because of its flexibility in focusing on human experience, emotional reactions, feelings, and "almost 
literally see and hear its people" (Burns, 1989, p. 48) rather than on more quantifiable variables. The study also employs a qualitative approach because it will help explore the unethical and dark side of organizations (Wincup, 2017), which can be undetected and unrecorded officially (Coleman \& Moynihan, 1996; Jamieson, 1998). Only a qualitative approach sticks as closely as possible to the original data to obtain unexplored and unexpected insights (Russel, 2000).

From a methodological viewpoint, descriptive analysis of obedience in organizations' face of unethical behavior is "difficult to observe and difficult to measure" because participating individuals keep their own stories and identities hidden (Collins et al., 2009). Therefore, the study did not use observation but interviews in natural settings. The reports received by qualitative researchers during interviews "will be stories of intense suffering, social injustices, or other things that will shock the researcher" (Morse \& Field, 1995, p. 78).

The argument put forward is based on indepth interviews with a small sample, with only ten informants (four top-level, four mediumlevel, and two low-level employees from six large-sized and four medium-sized enterprises) recruited, representing a small percentage of the total number of unethical employees in organizations. Indeed, investigating such a sensitive issue within organizations, which prize their secrecy, is not an easy task, mainly for an unfamiliar interviewer not known to the respondents. That is why only a few informants were involved in the study. However, small samples are much more manageable for practical reasons because of the quantity of potentially rich and detailed data generated from each informant. To this end, those interviewed included top, middle, and low-level employees in different types of medium-to-large private enterprises on Java Island. The informants also had varying ages and education levels, ranging from high school to master's level.

Before collecting the data, the informants were identified and approached. One of the researchers then described and explained the study's purpose and asked if they would like to participate voluntarily. Before interviews taking place, voluntary informed consent forms from all informants are needed. After obtaining these, the researcher requested permission to record each interview. Since the research topic required empathic and detailed information, an attempt was made to establish a comfortable and nonthreatening environment at the interviewees' home or a location of their choice.

To ensure the informants' safety, a guarantee was given that detailed descriptions of the interviewees and the interview content would not be disclosed. With the permission of the informants, the interviews were recorded and transcribed. The transcription was manually coded in great detail, shifting back and forth between the informant's points of view and the researcher's interpretation. The data analysis was mostly inductive; that is, "bottom-up" without formulated hypotheses and preconceived theories. The informants' overarching keywords were analyzed during and after interviews, and irrelevant conversations were left out. The interviews were conducted in Indonesian.

All informants were asked the same questions. Guiding questions were employed to elicit information on the obedience in the face of unethical behavior in organizations, such as "What led employees to accept unethical 
behavior?" and "How do employees justify obedience in the face of unethical behavior?" Because of the questions' sensitivity, as in corporate corruption, it is clearly important to keep careful records of the data to make informants secure and not hesitate in their answer. Furthermore, the researchers guaranteed the anonymity and confidentiality of the informants and locations for ethical reasons. The interview transcripts were painstakingly conducted to obtain accurate interviews and then read and re-read, possibly several times, before analyzing and interpreting the data.

\section{Results}

This section provides the findings on obedience in the face of unethical behavior among employees in the organizations. However, it was not the intention to blame certain employees or corporations. Rather, there is an interest in informing readers that people who engage in unethical behavior could be linked to any age, gender, education, or socioeconomic background. To make the analysis more specific and clearer, the research investigated into obedience in the face of unethical behavior in relation to corporate corruption, especially the offering of bribes to clients.

The study results demonstrate that obedience in the face of unethical behavior among employees is considered an organizational rule. A marketing employee, 28 years old, believed that obedience to one's leader was standard strategy to help the company survive; even though it is unethical, "it is considered a standard." It is known that organizational leadership plays a major role in determining an organization's standard operating procedure (SOP). This is because only top-level staff in organizations can decide such procedure. For this reason, it is understandable that unethical organizations not only select and retain unethical employees, but also create them (Cialdini et al., 2004).

Similarly, when the question was addressed to the interviewees about the reason why employees obey in the face of unethical behavior, a district sales manager of a multinational company, 42 years old, answered it confidently: "Right. This (giving bribery) is the habit of my organization." Through the employees' responses, it can be seen that some employees who did not recognize ethical principles were likely to accept unethical practices. The unethical habit made employees unaware of their illicit behavior. However, as far as they were concerned, the excuses that "This is the SOP of my company", "My boss asked me", or "I'm just following orders" reflect blind obedience. In this case, the organization leader instructs employees to engage in unethical behavior that they believe is clearly unethical; sometimes, perhaps often, the employees will obey, as being an employee typically means being vulnerable to losing one's job. Therefore, they obey orders without question, reason, or critical thinking. It also implies a way of acting in which people follow the rules without interpretation or consideration of objective meanings (Kotzee, 2014; Williams, 2010). As a result, it is not surprising that employees in organizations with unethical jobs are reluctant to reveal their problems, which might lead to new problems and jeopardize their future.

When asked: How does obedience in the face of unethical behavior become the standard in your organization? The results show that the leader has the authority to determine whether what employees are doing is acceptable or unacceptable. Some informants claimed that "the standard 
or agreement within the organization and contracts to clients are given directly by the boss."

While individuals are made to accept unethical behavior, they may simply be following what their coworkers are doing in the workplace. Employees tend to behave in accordance with their environment "as the way we do things around here" (Darley, 2005, p. 1187). Therefore, a "me too" mentality, which may perpetuate mindless conformity and lead to undesired effects for the company and stakeholders, could occur among organizational members. Furthermore, employees could accept unethical behavior in organizations because they are imitating and learning from their coworkers. This situation happens because of the neutralization and selflegitimization of psychological processes (Porta \& Vannucci, 2012). As a result, members of unethical organizations have tendencies to justify the acceptance of unethical behavior.

Accordingly, employees only do what their leaders expect of them, including ignoring ethical practices. Consequently, such unethical domination justifies repeated unethical behavior. The justification for unethical employees could be based on the argument that "no one is really going to be hurt," "no one will ever know," or "that it was someone else who was careless, not me" (Werhane et al., 2013). Indeed, the informants confessed that acceptance of unethical behavior made them feel insecure; the dilemma they faced over the issue was also profound. As a result, most employees were looking outside themselves for guidance on such ethical dilemmas (Treviño \& Brown, 2005).

The obligation to follow leaders and their orders is essential in hierarchical organizations. In a hierarchical organization and a situation in which obedience seems to be the norm (Bivins, 2006), organizational members will restrict their perceptions, thoughts, and emotions because such obedience frees them from personal responsibility and consequences. They become skilled at such justifications for unethical behavior because positive self-perceptions enable them to have benefits (Werhane et al., 2013). In short, selfdeception allows employees to justify engaging in unethical behavior while protecting them from the "psychological cost" (Chance \& Norton, 2008). If employees are accustomed to believing that they are ethical, regardless of what they do, this self-image enables them to bypass unethical decision-making (Werhane et al., 2013).

Besides, another argument made by the informants demonstrates that the middle-seniorlevel management of organizations often commands employees to obey their orders without question. This is seen as an acceptable means to reach the targets of the organization. For this reason, entry-level employees will also learn the organizational ideologies and then follow the culture that has been entrenched. Therefore, obedience to the leader is an instrument of indoctrination (Werhane et al., 2013). Nevertheless, justifying the ideology is particularly important for entry-level employees to deal with an unethical organization's reality shock (Minor, 1981).

\section{Discussion}

This study demonstrates that obedience in the face of unethical behavior among employees may exist when they believe that they are acting in their organization's interests when violating organizational values and rules. In these circumstances, there is a lack of intention to gain personal benefit. However, the dividing line 
between individual and organizational misbehavior is thin, as the organization and its culture almost always play a role in such unethical behavior, thus running the risk of illegal behavior eventually.

In Indonesian culture, people rely on organizational leaders, who become role models and are responsible for the organization. This is because the leaders have the authority to establish the rules and become the organization's center. Leaders or managers at any level can affect the behavior of employees. They are also publicly hailed and financially rewarded for achieving extraordinary financial outcomes, although no one seems to care what methods they use to achieve such outcomes. Therefore, it is not surprising to find that their subordinates followed their lead and became increasingly adept at inventing new (and sometimes unethical) ways to contribute to these outcomes (Treviño \& Brown, 2005).

In contrast, such employees may be motivated to obey commands because they believe that their obedience will please their leader, to whom they grateful for giving them their job. Consequently, they perceive that they can obtain promotion and play a significant role in the organization. Indeed, employees often focus on the chain of rewards and punishments (Arvey \& Jones, 1985; Kanfer, 1990; Trevino, 1992). However, the risks of accepting ethical or unethical behavior may affect their social status, economic security, or self-esteem (Milgram, 2011).

The analysis has revealed that perpetrators might have accepted unethical behavior for many different reasons. However, it is still the context shaped by leading figures that have provided them with the opportunity and motivation, and a sense of entitlement. Leaders can make employees believe that acceptance of unethical behavior is the right thing within a specific context. However, the potential dark side of such manifestations by leaders could be an issue for organizations. Leaders can also be manipulative and self-centered in the ways they achieve their goals (Parry \& Proctor-Thomson, 2002).

However, unethical organizations do not simply involve unethical practices committed solely for the benefit of the individual, such as bribery, fraud, embezzlement, or theft, which may harm the organization, but also unethical behavior that benefits the organization itself. Not surprisingly, many researchers argue that leaders are focused on achieving their targets. Organizational crime refers to those committed by members of respectable and reputable organizations, individually or in groups, in the context of the performance of their organizational tasks (van de Bunt, 1992, p. 6). Consequently, employees who accept unethical behavior remain hidden from companies. This is termed the "pathology" of organizations (Slapper \& Tombs, 1999).

To some extent, obedience is regarded as a virtue and is implemented by forceful and punitive strategies (Baumrind, 1966). Leadership styles are likely to be negatively influential and restrictive for employees' opportunities to develop their consciences. Werhane and Moriarty (2009) argue that many managers believe that good leadership primarily encourages employees to do what they want. In reality, individuals often follow immoral and hazardous instructions when instructed to do so by a person in authority. These corporate cultures may encourage employees to be passive bystanders, rather than actors with moral responsibility. They may be ill-prepared to recognize ethical crises or wrongdoing as issues 
that require their intervention (Werhane et al., 2013).

In some cases, employees may find obstacles to implementing ethical decisions. Such employees are likely to feel invisible, helpless, and incapable of summoning up the courage to speak out when unethical behavior occurs (Werhane et al., 2013). When instructed to act unethically, entry-level employees go through intense anxiety, which paves the way for the trap of obedience to authority. Indeed, this shows that emotions can make people extremely submissive and thus engage in wrongdoing (Kopicko, 2018). This study has shown that ordinary people simply accept unethical behavior at work, and they potentially become agent of a terrible destructive process without any particular hostile intent. Furthermore, "relatively few people have the resources needed to resist." (Milgram, 2011).

Indeed, some societies have availed a dictatorial work regime, and subordinate employees are forced to obey without question (Kopicko, 2018), later finding that it is impossible to reverse their actions. Therefore, this study is related to the Milgram experiment, which demonstrated that:

The person who, with inner conviction, loathes stealing, killing, and assault may find himself performing these acts with relative ease when commanded by authority. Behavior that is unthinkable in an individual who is acting on his own may be executed without hesitation when carried out under orders .... [I]nhumane policies may have originated in the mind of a single person. Still, they could only have been carried out on a massive scale if a very large number of people obeyed orders (Milgram, 1974, pp. xi-1).

The study also demonstrates that over time repeated exposure to dilemmas may eventually lead to a form of ethical numbing (Robertson \& Nichols, 2017), in which the ethical nature of the dilemma is no longer recognized as wrongdoing. However, in Indonesian society, ethics seem to be very "easy" to achieve, but in order to have an effective ethical code within an organization, leaders need to understand the essence of such ethics. Failure to understand this could end disastrously for the organization.

In Indonesia, most leaders of large corporations are usually law-abiding citizens with successful career paths, respectable, highly educated, ultra-religious, and of the uppermiddle or upper classes. Therefore, employees use a neutralization mechanism to justify why they behave the way they do; they try to maintain their self-image as respectable individuals. Such tactics are often reflected in the media reports or legal proceedings following criminal allegations (Kolthoff, 2020). In summary, when seeking profit and social responsibility are pursued together, moral conflict and hypocrisy are legitimate concerns.

\section{Conclusion}

The research was based on data collected from employees of private sector organizations in provinces on Java Island. By gaining a deeper understanding of the psychology of misbehavior in the workplace, this descriptive qualitative study has discussed how employees accept unethical behavior in the organization. The analysis has revealed that such acceptance is based on the rules and habits of organization. The informants also explained how organizational members justify their misbehavior. Assumptions based on "nobody will be hurt" could neutralize their feelings of insecurity. Creating greater benefits for the 
organization has also become a further excuse to justify the unacceptable practice.

From the study, readers could explore what lessons can be learned from an organization that claims to be ethical but does not place ethics at its heart. This practice raises a vital question regarding its ethical seriousness.]

\section{References}

Arvey, R. D., \& Jones, A. P. (1985). The use of discipline in organizational settings: A framework for future research. Research in Organizational Behavior, 7, 367-408.

Baumrind, D. (1966). Effects of authoritative parental control on child behavior. Child Development, 37(4), 887-907. https://doi.org/10.2307/1126611

Bivins, H. T. (2006). Responsibility and accountability. In K. Fitzpatrick \& C. Bronstein (Eds.), Ethics in public relations: Responsible advocacy (pp. 19-38). Thousand Oaks, CA: SAGE Publication Inc.

Brannigan, A. (2012). Genocide in Rwanda: From pathological altruism to pathological obedience. In B. Oakley, A. Knafo, G. Madhavan, \& D. S. Wilson (Eds.), Pathological altruism (pp. 225-236). New York: Oxford University Press.

Burns, N. (1989). Standards for qualitative research. Nursing Science Quarterly, 2(1), 44-52. https://doi.org/10.1177/089431848900200112

Cadsby, C. B., Maynes, E., \& Trivedi, V. U. (2006). Tax compliance and obedience to authority at home and in the lab: A new experimental approach. Experimental Economics, 9(4), 343-359. https://doi.org/10.1007/s10683-006-7053-8

Caiden, G. E. (2007). Corruption and governance. In W. L. Richter \& F. Burke (Eds.), Combating corruption, encouraging ethics: A practical guide to management ethics (pp. 79-80). Plymouth UK: Rowman and Littlefield Publishers, Inc.

Chance, Z., \& Norton, M. I. (2008). I read playboy for the articles: Justifying and rationalizing questionable preferences. In M. S. McGlone \& M. L. Knapp (Eds.), The interplay of truth and deception. Oxfordshire: Routledge.

Cialdini, R. B., Petrova, P. K., \& Goldstein, N. J. (2004, March). The hidden costs of organizational dishonesty. MIT Sloan Management Review, 45(3), 67-73.

Coleman, C., \& Moynihan, J. (1996). Understanding crime data. Ballmoor, Buckingham: Open University Press.

Collins, J. D., Uhlenbruck, K., \& Rodriguez, P. (2009). Why firms engage in corruption: A top management perspective. Journal of Business Ethics, 87(1), 89-108. https://doi.org/10.1007/s10551-0089872-3

Darley, J. M. (2005). The cognitive and social psychology of contagious organizational corruption. Brooklyn Law Review, 70(4), 1177-1194.

de Graaf, G., Maravic, P. von, \& Waagenar, P. (Eds.). (2010). The good cause: Theoretical perspectives on corruption. Opladen: Verlag Barbara Budrich. https://doi.org/10.3224/86649263

Doig, A. (2005). Where corruption lives. Gerald E. Caiden, O. P. Dwivedi and Joseph Jabbra Kumarian Press, Inc., 2001, xii 273 pp., ISBN 156549133 5A cautionary tale: ten major flaws in 
combatting corruption. Gerald Caiden Southwestern Journal of Law and Trade in the Am. Public Administration and Development, 25(3), 270-271. https://doi.org/10.1002/pad.338

Giacalone, R. A., Knouse, S. B., \& Pollard, H. G. (1999). Willingness to report unethical behavior in exit surveys. Teaching Business Ethics, 3, 307-319.

Hamilton, G. G., \& Biggart, N. W. (1985). Why people obey: Theoretical observations on power and obedience in complex organizations. Sociological Perspectives, 28(1), 3-28. https://doi.org/10.2307/1389072

Harrendorf, S. (2014). How can criminology contribute to an explanation of international crimes? Journal of International Criminal Justice, 12(2), 231-252. https://doi.org/10.1093/jicj/mqu020

Heath, J. (2008). Business ethics and moral motivation: A criminological perspective. Journal of Business Ethics, 83(4), 595-614. https://doi.org/10.1007/s10551-007-9641-8

Hoyk, R., \& Hersey, P. (2009). The root causes of unethical behavior. Graziadio Business Review, 12(1), 15.

Ivcevic, Z., Menges, J. I., \& Miller, A. (2020, March 20). How common is unethical behavior in U.S. organizations? Havard Business Review. https://hbr.org/2020/03/how-common-is-unethicalbehavior-in-u-s-organizations

Jamieson, L. (1998). Understanding crime data: Haunted by the dark figure. By Clive Coleman and Jenny Moynihan. Open University Press, 22 Ballmoor, Buckingham, MK18 1XW, September 1996, 160 pp. ISBN 0-335-195519-9. ISBN 0-335-19518-0. Criminal Behaviour and Mental Health, 8(3), 241-242. https://doi.org/10.1002/cbm.261

Javaid, M. F., Raoof, R., Farooq, M., \& Arshad, M. (2020). Unethical leadership and crimes of obedience: A moral awareness perspective. Global Business and Organizational Excellence, 39(5), 18-25. https://doi.org/10.1002/joe.22011

Kanfer, R. (1990). Motivation theory and industrial and organizational psychology. In M. D. Dunnette \& L. M. Hough (Eds.), Handbook of industrial and organizational psychology (pp. 75-170). Palo Alto, CA: Consulting Psychologists.

Kaptein, M., \& Avelino, S. (2005). Measuring corporate integrity: A survey-based approach. Corporate Governance: The International Journal of Business in Society, 5(1), 45-54. https://doi.org/10.1108/14720700510583467

Kemper, T. D. (1966). Representative roles and the legitimation of deviance. Social Problems, 13(3), 288298. https://doi.org/10.1525/sp.1966.13.3.03a00040

Kolthoff, E. W. (2020). Criminological responses to corruption. In A. Graycar (Ed.), Handbook on corruption, ethics and itegrity in public ddministration (pp. 434-448). Cheltenham, UK: Edward Elgar Publishing Ltd.

Kopicko, M. S. (2018). Why employees and managers engage in unethical practices. Senior Honors Theses. https://commons.emich.edu/honors/590

Kotzee, B. (2014). [Book Review] Blind obedience: paradox and learning in the later Wittgenstein - by Meredith Williams; The formation of reason - by David Bakhurst. British Journal of Educational Studies, 62(1), 86-89. https://doi.org/10.1080/00071005.2013.877634

Litz, R. (2000). Moral imagination and management decision making. Academy of Management Review, 25(1), 256-259. https://doi.org/10.5465/amr.2000.2791616

Martiar, N. A. D., \& Purnamasari, D. D. (2020, June 3). Enam terdakwa kasus Jiwasraya didakwa rugikan $\begin{array}{lllll}\text { negara } & \text { hingga } & R p & 16,807 & \text { triliun. }\end{array}$ 
https://www.kompas.id/baca/polhuk/2020/06/03/enam-terdakwa-kasus-jiwasrayadidakwa-rugikan-negara-hingga-rp-16807-triliun/

Mayer, D. M., Kuenzi, M., Greenbaum, R., Bardes, M., \& Salvador, R. (Bombie). (2009). How low does ethical leadership flow? Test of a trickle-down model. Organizational Behavior and Human Decision Processes, 108(1), 1-13. https://doi.org/10.1016/j.obhdp.2008.04.002

Milgram, S. (1974). Obedience to authority: An experimental view. Harper \& Row.

Milgram, S. (2011). The perils of obedience. In L. Behrens \& L. J. Rosen (Eds.), Writing and reading across the curriculum (pp. 692-704). Pearson.

Minor, W. W. (1981). Techniques of neutralization: a Reconceptualization and empirical examination. Journal of Research in Crime and Delinquency, 18(2), 295-318. https://doi.org/10.1177/002242788101800206

Morse, J. M., \& Field, P. A. (1995). Qualitative research methods for health professionals. Sage Publication Inc.

MS. (2019, December 5). Garuda CEO Ari Askhara dismissed amid smuggling scandal. IDN Financial. https://www.idnfinancials.com/news/30605/garuda-ceo-ari-askhara-dismissed-smugglingscandal

Parry, K., \& Proctor-Thomson, S. (2002). Perceived integrity of transformational leaders in organisational settings. Journal of Business Ethics, 35, 75-96.

Porta, D. della, \& Vannucci, A. (2012). The hidden order of corruption: An institutional approach. Farnham UK: Ashgate.

Robertson, D. C., \& Nichols, P. M. (2017). Introduction and Overview: Bribery and the Study of Decision Making. In P. Nichols \& D. C. Robertson (Eds.), Thinking about bribery: Neuroscience, moral cognition and the psychology of bribery (pp. xv-xvi). Cambridge University Press. https://doi.org/10.1017/9781316450765.001

Russel, \& B.H. (2012). Social research methods: Qualitative and quantitative approaches. SAGE Publication Inc.

Schaubroeck, J. M., Hannah, S. T., Avolio, B. J., Kozlowski, S. W. J., Lord, R. G., Treviño, L. K., Dimotakis, N., \& Peng, A. C. (2012). Embedding ethical leadership within and across organization levels. Academy of Management Journal, 55(5), 1053-1078. https://doi.org/10.5465/amj.2011.0064

Skitka, L. J., Bauman, C. W., \& Lytle, B. L. (2009). Limits on legitimacy: Moral and religious convictions as constraints on deference to authority. Journal of Personality and Social Psychology, 97(4), 567578. https://doi.org/10.1037/a0015998

Slapper, G., \& Tombs, S. (1999). Corporate crime. Longman.

Trevino, L. K. (1992). The social effects of punishment in organizations: A justice perspective. The Academy of Management Review, 17(4), 647-676. https://doi.org/10.2307/258803

Treviño, L. K., \& Brown, M. E. (2005). The role of leaders in influencing unethical behavior in the workplace. In R. Kidwell \& C. L. Martin (Eds.), Managing organizational deviance (pp. 69-96). Thousand Oaks: SAGE Publication Inc.

van de Bunt, H. G. (1992). Organisatiecriminaliteit (Organization crime). Gouda Quint.

Werhane, P. H., Hartman, L. P., Archer, C., Englehardt, E. E., \& Pritchard, M. S. (2013). Obstacles to ethical decision-making: Mental models, Milgram and the problem of obedience. Cambridge University Press. https://doi.org/10.1017/CB09780511675911 
Williams, M. (2010). Blind obedience: Paradox and learning in the later Wittgenstein. Routledge.

Wincup, E. (2017). Criminological research: Understanding qualitative methods. SAGE Publication Inc.

Zimbardo, P. G. (2007). The Lucifer effect: how good people turn evil. Random House Inc. 